\title{
Hepatitis B virus infection and the risk of nonalcoholic fatty liver disease: a meta-analysis
}

\author{
Jianping Xiong ${ }^{1, *}$, Haoaohai Zhang, ${ }^{1,}$, Yaqin Wang ${ }^{2}$, Anqiang Wang ${ }^{1}$, Jin Bian ${ }^{1}$, \\ Hanchun Huang ${ }^{1}$, Ying Zheng ${ }^{3}$, Xinting Sang ${ }^{1}$, Yiyao $X_{u^{1}}{ }^{1}$ Xin Lu ${ }^{1}$ and Haitao Zhao ${ }^{1}$ \\ ${ }^{1}$ Department of Liver Surgery, Peking Union Medical College Hospital, Chinese Academy of Medical Sciences and Peking \\ Union Medical College, Beijing, China \\ ${ }^{2}$ Department of Interventional Radiology, The First Affiliated Hospital of China Medical University, Shenyang, China \\ ${ }^{3}$ State Key Laboratory of Quality Research in Chinese Medicine, Institute of Chinese Medical Science, University of Macau, \\ Macau SAR, China \\ *These authors contributed equally to this work
}

Correspondence to: Yiyao Xu, email: xuyiyao@hotmail.com Xin Lu, email: luxinln@163.com

Haitao Zhao, email: ZhaoHT@pumch.cn

Keywords: hepatitis $B$ Virus, nonalcoholic fatty liver disease, meta-analysis

Received: April 04, 2017 Accepted: September 04, 2017 Published: November 03, 2017

Copyright: Xiong et al. This is an open-access article distributed under the terms of the Creative Commons Attribution License 3.0 (CC BY 3.0), which permits unrestricted use, distribution, and reproduction in any medium, provided the original author and source are credited.

\section{ABSTRACT}

Some studies have reported that hepatitis B virus (HBV) infection affects the risk of nonalcoholic fatty liver disease (NAFLD). However, this association is controversial. We conducted a systematic review and meta-analysis to investigate the relationship between HBV infection and NAFLD. Relevant studies published before May 2017 were identified by searching PubMed, EMBASE, and ISI Web of Science. We used the random-effects model proposed by DerSimonian and Laird to quantify the relationship between HBV infection and risk of NAFLD. We also conducted subgroup and sensitivity analyses to validate the stability of the results. Five articles, comprising 8,272 HBVinfected patients and 111,631 uninfected controls, were included in our research. Our meta-analysis suggested that the risk of NAFLD was significantly lower in HBVinfected patients than in uninfected controls, with heterogeneity between studies (summary odds ratio $[\mathrm{OR}]=0.71$; confidence interval $[\mathrm{CI}]=0.53-0.90 ; \mathrm{I}^{2}=75.2 \%$ ). However, the inverse relationship was observed in only cohort (OR $=0.83 ; 95 \%$ $\mathrm{CI}=0.73-0.94)$ and cross-sectional studies $(\mathrm{OR}=0.63 ; 95 \% \mathrm{CI}=0.47-0.79)$, not case-control studies (OR $=3.96 ; 95 \% \mathrm{CI}=2.10-7.48)$. In conclusion, HBV infection was inversely associated with the risk of NAFLD.

\section{INTRODUCTION}

Nonalcoholic fatty liver disease (NAFLD) is the most common cause of chronic liver disease, affecting approximately $20-25 \%$ of U.S. adults [1-3]. In addition, NAFLD is an independent risk factor that is associated with an increased incidence of cirrhosis and primary liver cancer. Studies have reported that up to $9 \%$ of patients with NAFLD progress to liver fibrosis, cirrhosis and eventually hepatocellular carcinoma [4-7]. However, the pathogenesis of NAFLD is not well understood. Only a few risk factors have been recognized, including obesity, diabetes mellitus, and hyperlipidemia, and most of these factors are metabolically related [8-10]. Thus, an increasing number of researchers consider NAFLD to be a feature of metabolic syndrome [11-13]. Recent studies have reported an inverse relationship between hepatitis B virus (HBV) infection and metabolic syndrome $[14,15]$. However, few studies have examined the effect of HBV infection on the risk of NAFLD, and the association between HBV infection and NAFLD remains controversial. HBV infection is a primary cause of the global health burden. An estimated 350 million people-i.e., $5 \%-7 \%$ of the world's population-are chronic carriers of $\mathrm{HBV}, 75 \%$ of whom live in the Asia Pacific 
Region [16, 17]. Moreover, HBV infection is the leading cause of chronic liver disease, especially cirrhosis and hepatocellular carcinoma [18]. At least a third of patients with cirrhosis and $75 \%$ of patients with primary liver cancer have HBV [19, 20], and approximately 1 million people die of acute and chronic HBV infection every year [21]. Accordingly, we conducted a systematic review and meta-analysis of published observational studies to better understand the relationship between HBV infection and the risk of NAFLD.

\section{RESULTS}

\section{Study selection and study characteristics}

Figure 1 shows the study selection process. We obtained 5759 articles through the initial search (1303 from PubMed, 3436 from EMBASE, 1020 from Web of Science), 3120 of which were duplicates. We excluded 2392 more studies after reviewing the titles and abstracts, and three more studies were further excluded due to having insufficient information such as date unavailable, not relevant exposure and not relevant outcome [22-25]. Therefore, five eligible observational articles were included in our meta-analysis [26-30].

The main characteristics of the included studies are listed in Table 1 [26-30]. Two studies were performed in Taiwan, one in China, one in Korea and one in Hong Kong. All included studies were observational studies and included three cross-sectional [26, 27, 30], one casecontrol [29] and one cohort study [28]. The meta-analysis included 8,272 patients with HBV infection and 111,631 uninfected controls to explore the effect of HBV infection on the risk of NAFLD. The data analyzed in the studies were collected from 2002 to 2014. The modified NOS scores of the included studies ranged from 5 to 9 , with four high-quality studies and only one of medium quality (Table 3).

\section{Association between $\mathrm{HBV}$ infection and risk of NAFLD}

Five studies [26-30] were included to investigate the relationship between $\mathrm{HBV}$ infection and the risk of
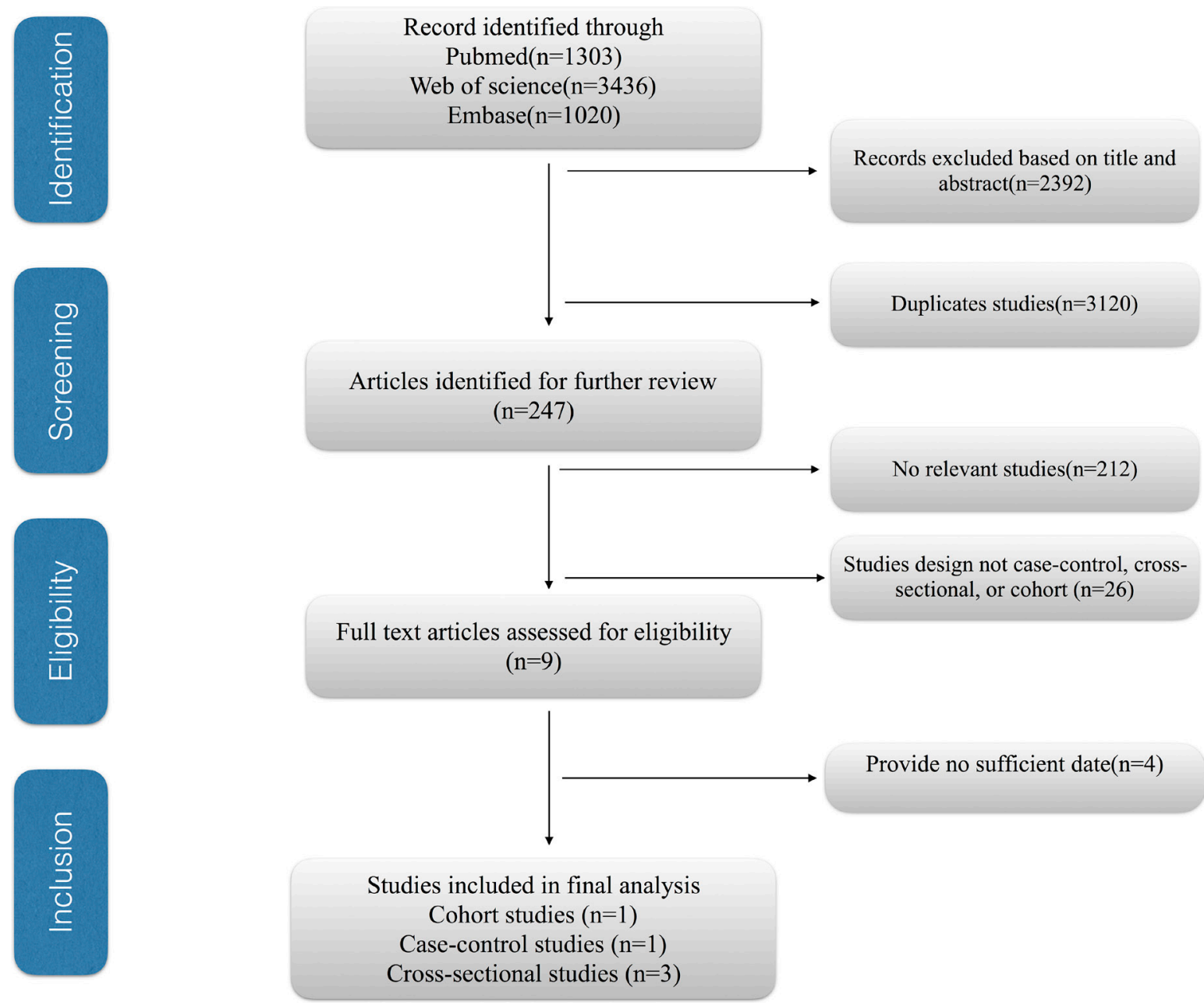

Figure 1: The study selection process for the meta-analysis. 


\section{Table 1: The main characteristics of the included studies}

\begin{tabular}{|c|c|c|c|c|c|c|c|c|c|}
\hline \multicolumn{10}{|c|}{ HBV and NAFLD } \\
\hline $\begin{array}{c}\text { Study/Years } \\
\text { of } \\
\text { Publication }\end{array}$ & Country & $\mathrm{HBV}+/ \mathrm{HBV}-$ & Follow & $\begin{array}{l}\text { Sources of } \\
\text { Controls }\end{array}$ & Outcome & $\begin{array}{c}\text { Subtype } \\
\text { of } \\
\text { study }\end{array}$ & Exposure & Adjusted Factors & $\begin{array}{c}\text { Adjusted OR/RR } \\
(95 \% \mathrm{CI})\end{array}$ \\
\hline $\begin{array}{c}\text { Vincent } \\
\text { Wai-Sun } \\
\text { Wong.2012 }\end{array}$ & $\begin{array}{l}\text { Hong } \\
\text { Kong }\end{array}$ & $91 / 922$ & $2008-2010$ & population & NAFLD & $\begin{array}{c}\text { cross- } \\
\text { sectional }\end{array}$ & HBV & $\begin{array}{c}\text { alcohol } \\
\text { consumption, } \\
\text { demographic, and } \\
\text { metabolic factors }\end{array}$ & $0.42(0.20,0.88)$ \\
\hline $\begin{array}{l}\text { Yuan-Lung } \\
\text { Cheng.2013 }\end{array}$ & Taiwan & $3642 / 29797$ & 2002-2009 & hospital & NAFLD & $\begin{array}{c}\text { cross- } \\
\text { sectional }\end{array}$ & HBV & $\begin{array}{c}\text { age, sex, } \\
\text { BMI,WC,SBP, } \\
\text { fasting glucose, } \\
\text { cholesterol, LDL, } \\
\text { TG, ALT, GGT, } \\
\text { platelet counts, } \\
\text { FLI }\end{array}$ & $0.66(0.59,0.72)$ \\
\hline $\begin{array}{c}\text { Eun-Jeong } \\
\text { Joo.2016 }\end{array}$ & Korea & $3926 / 79413$ & 2002-2014 & population & NAFLD & cohort & HBV & $\begin{array}{l}\text { age, sex, year of } \\
\text { visit, smoking } \\
\text { status, alcohol } \\
\text { intake, regular } \\
\text { exercise, } \\
\text { education level, } \\
\text { and body mass } \\
\text { index }\end{array}$ & $0.83(0.73,0.94)$ \\
\hline $\begin{array}{c}\text { Chia-Chi } \\
\text { Wang.2007 }\end{array}$ & Taiwan & $50 / 457$ & NR & hospital & NAFLD & $\begin{array}{l}\text { case- } \\
\text { control }\end{array}$ & HBV & $\begin{array}{l}\text { age, sex, ALT, } \\
\text { riglyceride, total } \\
\text { cholesterol, Body } \\
\text { mass index, } \\
\text { fasting blood } \\
\text { glucose }\end{array}$ & $0.97(0.48,1.95)$ \\
\hline $\begin{array}{c}\text { Peng } \\
\text { XE.2013 }\end{array}$ & China & $527 / 1042$ & $2007-2008$ & hospital & NAFLD & $\begin{array}{c}\text { cross- } \\
\text { sectional }\end{array}$ & HBV & NR & $3.96(2.10,7.48)$ \\
\hline
\end{tabular}

RR, relative risk. OR, odds ratio. CI, confidence interval. NAFLD, nonalcoholic fatty liver disease. NR, no report. BMI, body mass index. WC, waist circumference. SBP, systolic blood pressure. HDL, high-density lipoprotein. LDL, low-density lipoprotein. TG, triglyceride. ALT, alanine aminotransferase. GGT, gamma-glutamyltransferase.

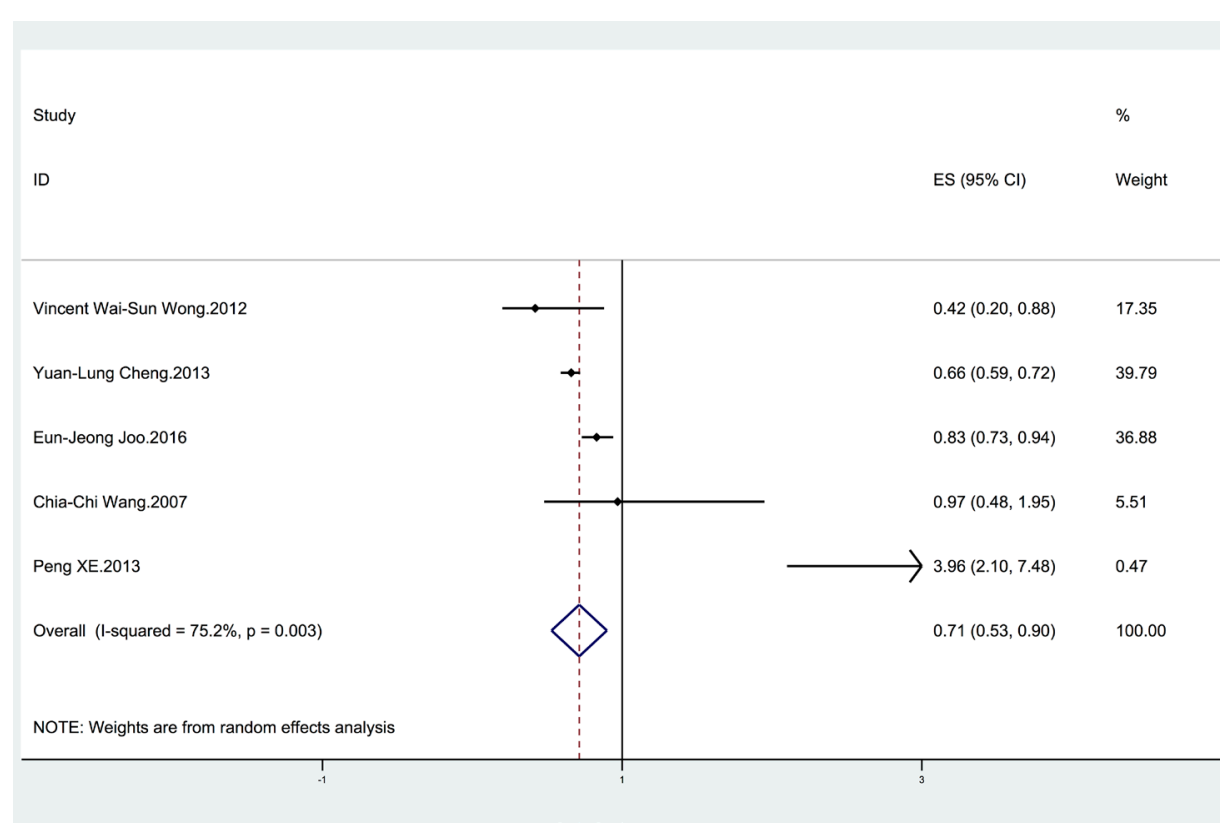

Figure 2: Forest plot showing the relationship between HBV infection and the risk of NAFLD. The horizontal axis is the $\mathrm{X}$ axis. The points represent the risk estimate of each individual study. Horizontal lines represent $95 \%$ confidence intervals; diamonds represent the summary risk estimate with $95 \%$ confidence interval. HBV, hepatitis B virus. NAFLD, nonalcoholic fatty liver disease. CI, confidence interval. ES, effect size. 
Table 2: Subgroup and sensitive analyses for $\mathrm{HBV}$ infection on the risk of NAFLD

\begin{tabular}{|c|c|c|c|c|}
\hline Subgroup & No. of studies & $\operatorname{RR}(95 \% C I)$ & $I^{2}$ value $(\%)$ & $P$ value \\
\hline All studies & 5 & $0.71(0.53,0.90)$ & 75.2 & 0.006 \\
\hline \multicolumn{5}{|l|}{ Study quality } \\
\hline$\geq 7$ & 4 & $0.70(0.55,0.86)$ & 71.3 & 0.015 \\
\hline$<7$ & 1 & $3.96(2.1,7.48)$ & - & - \\
\hline \multicolumn{5}{|l|}{ Study design } \\
\hline Cohort & 1 & $0.83(0.73,0.94)$ & - & - \\
\hline Case control & 1 & $3.96(2.10,7.48)$ & - & - \\
\hline Cross sectional & 3 & $0.63(0.47,0.79)$ & 21.9 & 0.278 \\
\hline \multicolumn{5}{|l|}{ Adjustment for confounders } \\
\hline \multicolumn{5}{|l|}{ Alcohol intake } \\
\hline Yes & 2 & $0.66(0.26,0.92)$ & 80.4 & 0.024 \\
\hline No & 3 & $1.02(0.23,1.81)$ & 69.0 & 0.040 \\
\hline \multicolumn{5}{|l|}{ Cholesterol level } \\
\hline Yes & 3 & $0.63(0.47,0.79)$ & 71.3 & 0.015 \\
\hline No & 2 & $0.92(0.81,1.61)$ & 80.7 & 0.203 \\
\hline \multicolumn{5}{|l|}{ Diabetes } \\
\hline Yes & 3 & $0.63(0.47,0.79)$ & 21.9 & 0.278 \\
\hline No & 2 & $0.92(0.81,1.61)$ & 80.7 & 0.203 \\
\hline \multicolumn{5}{|l|}{ Diagnosis of fatty liver } \\
\hline Ultrasound & 4 & $0.77(0.57,0.97)$ & 77.6 & 0.004 \\
\hline H-MRS & 1 & $0.42(0.20,0.88)$ & - & - \\
\hline \multicolumn{5}{|l|}{ Sensitive analyses } \\
\hline High quality studies & 4 & $0.70(0.55,0.86)$ & 71.3 & 0.015 \\
\hline Excluding the study using MRS & 4 & $0.77(0.57,0.97)$ & 77.6 & 0.004 \\
\hline \multicolumn{5}{|l|}{$\begin{array}{l}\text { Fixed-effects vs random-effects } \\
\text { model method }\end{array}$} \\
\hline Fixed-effects model & 5 & $0.70(0.65,0.76)$ & 75.2 & 0.003 \\
\hline Random-effects model & 5 & $0.71(0.53,0.90)$ & 75.2 & 0.003 \\
\hline
\end{tabular}

HBV, hepatitis B virus. NAFLD, nonalcoholic fatty liver disease. RR, relative risk; CI, confidence interval.

NAFLD (Table 1). Three studies [26-28] suggested that HBV infection was associated with a decreased risk of NAFLD. Only one study [30] reported a significantly higher risk of NAFLD in HBV-infected patients than in uninfected controls. The remaining studies [29] did not show a significant relationship. The pooled estimate was significant $(\mathrm{OR}=0.71 ; 95 \% \mathrm{CI}=0.53-0.90)$, with significant heterogeneity $\left(\mathrm{I}^{2}=75.2 \% ; p=0.003\right)$ (Figure 2$)$.

\section{Subgroup and sensitivity analyses}

The results of the subgroup analyses and sensitivity analyses are shown in Table 2. When the analysis was stratified by study quality, study design and adjustment for cholesterol level or diabetes in the models, there was a significant difference between subgroups $(P<0.05)$ (Table 2). For example, HBV infection was significantly associated with the risk of NAFLD in cohort $(\mathrm{OR}=0.83$; $95 \% \mathrm{CI}=0.73-0.94)$ and cross-sectional studies $(\mathrm{OR}=$
$0.63 ; 95 \% \mathrm{CI}=0.47-0.79)$, but not in case-control studies $(\mathrm{OR}=3.96 ; 95 \% \mathrm{CI}=2.10-7.48)$ (Table 2). According to the sensitivity analyses, despite excluded the study using MRS, the results of the relationship between HBV infection and NAFLD remained stable $(\mathrm{OR}=0.77 ; 95 \%$ $\mathrm{CI}=0.57-0.97)$. Additionally, the overall results remained consistent when the pooling model was changed (fixedeffects model: $\mathrm{OR}=0.70 ; 95 \% \mathrm{CI}=0.65-0.76$ and random-effects model: $\mathrm{OR}=0.71 ; 95 \% \mathrm{CI}=0.53-0.90)$.

\section{Publication bias}

The number of studies included in this meta-analysis was insufficient to assess publication bias $(<10)$.

\section{DISCUSSION}

To our knowledge, this is the first meta-analysis to investigate the relationship between HBV infection and 
Table 3: Scores of the modified Newcastle-Ottawa scale for studies

\begin{tabular}{|c|c|c|c|c|c|c|c|c|c|}
\hline $\begin{array}{l}\text { Study/Years } \\
\text { of } \\
\text { Publication }\end{array}$ & $\begin{array}{l}\text { Fully } \\
\text { defined } \\
\text { cases }\end{array}$ & $\begin{array}{l}\text { Define } \\
\text { the study } \\
\text { design }\end{array}$ & $\begin{array}{l}\text { Selection } \\
\text { of controls }\end{array}$ & $\begin{array}{l}\text { Described } \\
\text { the general } \\
\text { characteristics }\end{array}$ & $\begin{array}{l}\text { Controlling the } \\
\text { important factors } \\
\text { or confounding } \\
\text { factors. }\end{array}$ & $\begin{array}{l}\text { List inclusion } \\
\text { and exclusion } \\
\text { criteria for all } \\
\text { the participants }\end{array}$ & $\begin{array}{l}\text { Provided } \\
\text { enrollment } \\
\text { duration } \\
\text { for all the } \\
\text { participants }\end{array}$ & $\begin{array}{l}\text { Indicate } \\
\text { study period } \\
\text { and follow- } \\
\text { up duration }\end{array}$ & $\begin{array}{l}\text { Total } \\
\text { score }\end{array}$ \\
\hline $\begin{array}{l}\text { Vincent Wai- } \\
\text { Sun.2012 }\end{array}$ & $*$ & $*$ & & * & ** & $*$ & $*$ & $*$ & 8 \\
\hline $\begin{array}{l}\text { Yuan-Lung } \\
\text { Cheng.2013 }\end{array}$ & * & * & & * & ** & $*$ & & * & 7 \\
\hline $\begin{array}{l}\text { Eun-Jeong } \\
\text { Joo.2016 }\end{array}$ & * & * & * & * & $* *$ & $*$ & * & * & 9 \\
\hline $\begin{array}{l}\text { Chia-Chi } \\
\text { Wang.2007 }\end{array}$ & $*$ & * & & * & $* *$ & $*$ & $*$ & & 7 \\
\hline $\begin{array}{l}\text { Peng } \\
\text { XE.2013 }\end{array}$ & * & $*$ & * & $*$ & & & & * & 6 \\
\hline
\end{tabular}

The asterisks represent a score (number of stars).

the risk of NAFLD. Five studies were included to examine the effect of HBV infection on the risk of NAFLD, and the analyses showed that the risk of NAFLD was significantly lower in the 8,272 $\mathrm{HBV}$-infected patients than in the 111,631 uninfected controls $(\mathrm{OR}=0.71 ; 95 \%$ $\mathrm{CI}=0.53-0.90)$, with significant heterogeneity between studies. This effect was observed in cohort and crosssectional studies, but case-control studies did not reveal an inverse relationship between HBV infection and the risk of NAFLD.

Our study demonstrated only an association between $\mathrm{HBV}$ infection and a reduced risk of NAFLD; the data could not establish a causative role of HBV in this regard. The potential biological mechanisms of this finding include the following. Studies have reported that patients with HBV infection have a lower level of triglycerides, which may affect the development of NAFLD [31]. Additionally, studies have suggested that HBV X protein can inhibit the secretion of apolipoprotein B, which is an important component of the formation of very-lowdensity lipoprotein and low-density lipoprotein [32, 33]. In addition, other studies have indicated the association between HBV seropositivity and low serum cholesterol levels [34, 35].

Our study has several strengths. First, it is the first meta-analysis with a large sample size $(8,272 \mathrm{HBV}$ infected patients and 111,631 uninfected controls) to evaluate the effect of HBV infection on the risk of NAFLD. Therefore, the findings may provide insight into the relationship between HBV infection and NAFLD. In human studies, HBV infection affects the secretion of various adipokines and may alter the lipid profile $[36,37]$. As an analogy, lipid metabolism has been implicated in hepatitis $C$ viral entry, replication and response to treatment [38]. Hepatitis B virus replication may affect lipid metabolism and this warrants further studies. From a clinical standpoint, further studies on the mechanism linking lipid metabolism and HBV replicative cycle may shed light on new treatment targets on NAFLD [26]. Second, subgroup and sensitivity analyses were performed to determine the factors that may have affected the results and improved the reliability of our findings. Third, we performed a comprehensive literature search of the PubMed, EMBASE and Web of Science databases to identify potential studies to investigate the relationships between HBV infection and the risk of NAFLD. In addition, most of the studies included in our meta-analysis were of high quality. These characteristics make the conclusions of our study more persuasive.

There are several limitations that should be considered. First, the studies included in our meta-analysis used different methods to diagnose the NAFLD outcomes, including ultrasound and proton-magnetic resonance spectroscopy (H-MRS) [39]. The results of studies with different diagnostic measures were combined, which leads to concern regarding heterogeneity in the meta-analysis. In addition, the methodological differences may limit the comparability of studies and influence the impact identified on NAFLD risk. Second, the findings presented only an association, which is subject to confounding bias. Although we considered and discussed a number of adjustment factors, many potential adjustment factors were not included, such as physical activity and other dietary factors. For example, hepatitis B patients may pay more attention to physical activity and have good dietary habits, which have been shown to affect the development of NAFLD in previous studies [40-43]. In addition, we failed to obtain information about HBV-infected patients' use of antiviral treatment, which may have influenced the development of NAFLD. Third, all of the included studies in our meta-analysis were performed in Asia, and it is thus difficult to generalize our findings to the general population. Finally, only five studies were included in our article, placing the meta-analysis at a high risk of 
publication bias. Additionally, due to the different study designs and demographic characteristics, the heterogeneity between studies was significant and may be considered another potential limitation of this study. In addition, most of the studies included in our meta-analysis were casecontrol and cross-sectional studies; case-control designs are prone to recall and selection biases and cross-sectional designs have insufficient power to evaluate the relationship between HBV infection and the risk of NAFLD.

In summary, our meta-analysis indicated that HBV infection is associated with a lower prevalence of NAFLD, and the inverse relationship was demonstrated in cohort and cross-sectional studies only, not in case-control studies. More prospective studies and basic research should be conducted to further validate the association between HBV and NAFLD and to examine the potential mechanisms involved.

\section{MATERIALS AND METHODS}

\section{Data sources and search strategy}

We searched published reports in the PubMed, EMBASE and Web of Science databases using the following keywords: ("hepatitis B" OR "hepatitis B virus" OR "HBV") and ("fatty liver" OR "nonalcoholic fatty liver disease" OR "NAFLD" OR "nonalcoholic steatohepatitis" OR "NASH"). We placed no restrictions on the language or date of publication.

\section{Eligibility criteria for study selection}

The eligibility criteria were as follows: a crosssectional, case control or cohort study design; HBV as the exposure factor and NAFLD as the outcome; and odds ratio $(\mathrm{OR})$ /risk ratio (RR) values and corresponding 95\% confidence intervals (CIs) in the HBV-positive and HBVnegative groups described or sufficient information to calculate them. If two studies reported the same data, we selected the study with the larger sample.

\section{Data abstraction and quality assessment}

Two researchers independently extracted the required information from the selected studies in a standardized manner. We collected the following information from each article: first author's name, year of publication, country of origin, study design (crosssectional, case-control or cohort), number of participants, duration of follow-up, sources of controls, adjustment for confounding variables, and OR/RR values and 95\% $\mathrm{CIs}$ in the HBV-positive and HBV-negative groups. HBV infection is defined as HBsAg positive.

A universal scale that assesses the quality of all types of observational studies is not available. Therefore, two authors independently used the modified Newcastle-
Ottawa Scales (NOS) [44] reported by Wei Zhu [45] to evaluate the quality of the included studies. We assigned quality categories according to the scores of each study. Specifically, NOS scores of $<4,4-6$, and 7-9 indicated low-, medium-, and high-quality studies, respectively [46]. The maximum total score was 9 points. We resolved discrepancies by consensus.

\section{Statistical analyses}

The OR/RR values and corresponding 95\% CIs were used to evaluate the relationship between HBV infection and the risk of NAFLD. We treated hazard ratios as equivalent to RRs. We used the random-effects model proposed by DerSimonian and Laird to quantify the relationship between HBV infection and risk of NAFLD [47].

The $\mathrm{I}^{2}$ statistic was used to quantify the heterogeneity between studies, and $\mathrm{I}^{2}$ values of $25 \%$, $50 \%$, and $75 \%$ represented low, medium, and high heterogeneity, respectively [48]. $P$ values less than 0.1 indicated that clear heterogeneity existed. As this metaanalysis included less than ten studies, a funnel plot was not performed to evaluate publication bias [49].

We also performed subgroup analyses by study quality, study design and adjustment for alcohol intake, cholesterol level, diagnosis of fatty liver or diabetes in the models. Sensitivity analyses were also conducted by changing the pooling model (random-effects model or fixed-effects model), excluding the study using MRS and excluding studies with NOS scores $<7$.

All statistical analyses were performed using STATA version 12.0 (Stata).

\section{Abbreviations}

HBV, hepatitis B virus. NAFLD, nonalcoholic fatty liver disease.

\section{Author contributions}

J.X. designed the study and wrote this manuscript. H.Z. and Y.W. searched database and reviewed studies. A.W., J.B., H.H., Y.Z., Y.X. and X.S. collected and analyzed data. X.L. and H.Z. coordinated and provided financial support for this work. All of the authors have read and approved the final manuscript.

\section{CONFLICTS OF INTEREST}

None.

\section{FUNDING}

This work was supported by International Science and Technology Cooperation Projects (2015DFA30650 
and 2016YFE0107100), The Capital Special Research Project for the clinical application (Z151100004015170), Capital Special Research Project for Health Development (2014-2-4012), Beijing Nature Science Foundation for Young Scholars Project (7164293), Program for New Century Excellent Talents in University (NCET-11-0288).

\section{REFERENCES}

1. Clark JM, Brancati FL, Diehl AM. Nonalcoholic fatty liver disease. Gastroenterology. 2002; 122:1649-1657.

2. Chalasani N, Younossi Z, Lavine JE, Diehl AM, Brunt EM, Cusi K, Charlton M, Sanyal AJ. The diagnosis and management of non-alcoholic fatty liver disease: practice guideline by the American Gastroenterological Association, American Association for the Study of Liver Diseases, and American College of Gastroenterology. Gastroenterology. 2012; 142:1592-1609.

3. Loomba R, Sanyal AJ. The global NAFLD epidemic. Nature reviews Gastroenterology \& hepatology. 2013; 10:686-690.

4. Adams LA, Lymp JF, St Sauver J, Sanderson SO, Lindor KD, Feldstein A, Angulo P. The natural history of nonalcoholic fatty liver disease: a population-based cohort study. Gastroenterology. 2005; 129:113-121.

5. Starley BQ, Calcagno CJ, Harrison SA. Nonalcoholic fatty liver disease and hepatocellular carcinoma: a weighty connection. Hepatology (Baltimore, Md). 2010; 51:1820-1832.

6. Welzel TM, Graubard BI, Zeuzem S, El-Serag HB, Davila JA, McGlynn KA. Metabolic syndrome increases the risk of primary liver cancer in the United States: a study in the SEER-Medicare database. Hepatology (Baltimore, Md). 2011; 54:463-471.

7. Farrell GC, Larter CZ. Nonalcoholic fatty liver disease: from steatosis to cirrhosis. Hepatology (Baltimore, Md). 2006; 43:S99-S112.

8. Angulo P. Medical progress - Nonalcoholic fatty liver disease. New England Journal of Medicine. 2002; 346:1221-1231.

9. Hamaguchi M, Kojima $T$, Takeda N, Nakagawa $T$, Taniguchi H, Fujii K, Omatsu T, Nakajima T, Sarui H, Shimazaki M, Kato T, Okuda J, Ida K. The metabolic syndrome as a predictor of nonalcoholic fatty liver disease. Ann Intern Med. 2005; 143:722-728.

10. Fabbrini E, Sullivan S, Klein S. Obesity and Nonalcoholic Fatty Liver Disease: Biochemical, Metabolic, and Clinical Implications. Hepatology (Baltimore, Md). 2010; 51:679-689.

11. Marchesini G, Bugianesi E, Forlani G, Cerrelli F, Lenzi M, Manini R, Natale S, Vanni E, Villanova N, Melchionda N, Rizzetto M. Nonalcoholic fatty liver, steatohepatitis, and the metabolic syndrome. Hepatology (Baltimore, Md). 2003; 37:917-923.

12. Marchesini G, Brizi M, Bianchi G, Tomassetti S, Bugianesi E, Lenzi M, McCullough AJ, Natale S, Forlani G,
Melchionda N. Nonalcoholic fatty liver disease - A feature of the metabolic syndrome. Diabetes. 2001; 50:1844-1850.

13. Luo B, Wang Y, Wang K. Association of metabolic syndrome and hepatitis B infection in a Chinese population. Clinica Chimica Acta. 2007; 380:238-240.

14. Wang CC, Tseng TC, Kao JH. Hepatitis B virus infection and metabolic syndrome: fact or fiction? J Gastroenterol Hepatol. 2015; 30:14-20.

15. Jan CF, Chen CJ, Chiu YH, Chen LS, Wu HM, Huang CC, Yen MF, Chen TH. A population-based study investigating the association between metabolic syndrome and hepatitis $\mathrm{B} / \mathrm{C}$ infection (Keelung Community-based Integrated Screening study No. 10). International journal of obesity (2005). 2006; 30:794-799.

16. Alter MJ. Epidemiology of hepatitis B in Europe and worldwide. Journal of Hepatology. 2003; 39:64-69.

17. Kao JH, Chen DS. Global control of hepatitis B virus infection. The Lancet Infectious Diseases. 2002; 2:395-403.

18. Liaw YF, Chu CM. Hepatitis B virus infection. The Lancet. 373:582-592.

19. Chu CM, Liaw YF. Hepatitis B virus-related cirrhosis: natural history and treatment. Seminars in liver disease. 2006; 26:142-152.

20. Beasley RP. Hepatitis B virus. The major etiology of hepatocellular carcinoma. Cancer. 1988; 61:1942-1956.

21. Kane M. Global programme for control of hepatitis B infection. Vaccine. 1995; 13:S47-49.

22. Thomopoulos KC, Arvaniti V, Tsamantas AC, Dimitropoulou D, Gogos CA, Siagris D, Theocharis GJ, Labropoulou-Karatza C. Prevalence of liver steatosis in patients with chronic hepatitis B: a study of associated factors and of relationship with fibrosis. European journal of gastroenterology \& hepatology. 2006; 18:233-237.

23. Bondini S, Kallman J, Wheeler A, Prakash S, Gramlich T, Jondle DM, Younossi ZM. Impact of non-alcoholic fatty liver disease on chronic hepatitis B. Liver international. 2007; 27:607-611.

24. Pokorska-Spiewak M, Kowalik-Mikolajewska B, Aniszewska M, Pluta M, Walewska-Zielecka B, Marczynska M. Liver steatosis in children with chronic hepatitis B, C: Prevalence, predictors, and impact on disease progression. Medicine. 2017; 96:e5832.

25. Xu QH, Jie YS, Shu X, Chen LB, Cao H, Li G. [Relationship of fatty liver with HBV infection, hyperlipidemia and abnormal alanine aminotransferase]. [Article in Chinese]. Zhonghua shi yan he lin chuang bing du xue za zhi. 2009; 23:141-143.

26. Wong VW, Wong GL, Chu WC, Chim AM, Ong A, Yeung DK, Yiu KK, Chu SH, Chan HY, Woo J, Chan FK, Chan HL. Hepatitis B virus infection and fatty liver in the general population. J Hepatol. 2012; 56:533-540.

27. Cheng YL, Wang YJ, Kao WY, Chen PH, Huo TI, Huang YH, Lan KH, Su CW, Chan WL, Lin HC, Lee FY, Wu JC. 
Inverse Association between Hepatitis B Virus Infection and Fatty Liver Disease: A Large-Scale Study in Populations Seeking for Check-Up. PLoS ONE. 2013; 8:e72049.

28. Joo EJ, Chang Y, Yeom JS, Ryu S. Hepatitis B virus infection and decreased risk of nonalcoholic fatty liver disease: A cohort study. Hepatology (Baltimore, Md). 2017; 65:828-835.

29. Wang CC, Hsu CS, Liu CJ, Kao JH, Chen DS. Association of chronic hepatitis B virus infection with insulin resistance and hepatic steatosis. J Gastroenterol Hepatol. 2008; 23:779-782.

30. Peng XE, Chen FL, Wu YL, Lu QQ, Chen WN, $\mathrm{Xu} \mathrm{L}$. The roles of HBV infection and host factors in ultrasound-diagnosed fatty liver: a case-control study. Hepatogastroenterology. 2013; 60:1698-1704.

31. Liu J, Yang HI, Lee MH, Lu SN, Jen CL, Wang LY, You SL, Iloeje UH, Chen CJ. Incidence and determinants of spontaneous hepatitis B surface antigen seroclearance: a community-based follow-up study. Gastroenterology. 2010; 139:474-482.

32. Kang SK, Chung TW, Lee JY, Lee YC, Morton RE, $\mathrm{Kim} \mathrm{CH}$. The hepatitis B virus $\mathrm{X}$ protein inhibits secretion of apolipoprotein $\mathrm{B}$ by enhancing the expression of $\mathrm{N}$-acetylglucosaminyltransferase III. The Journal of biological chemistry. 2004; 279:28106-28112.

33. Chiang CH, Yang HI, Jen CL, Lu SN, Wang LY, You SL, Su J, Iloeje UH, Chen CJ. Association between obesity, hypertriglyceridemia and low hepatitis B viral load. International journal of obesity (2005). 2013; 37:410-415.

34. Su TC, Lee YT, Cheng TJ, Chien HP, Wang JD. Chronic hepatitis B virus infection and dyslipidemia. Journal of the Formosan Medical Association. 2004; 103:286-291.

35. Chen JY, Wang JH, Lin CY, Chen PF, Tseng PL, Chen CH, Chang KC, Tsai LS, Chen SC, Lu SN. Lower prevalence of hypercholesterolemia and hyperglyceridemia found in subjects with seropositivity for both hepatitis B, C strains independently. J Gastroenterol Hepatol. 2010; 25:1763-1768.

36. Wong VW, Wong GL, Yu J, Choi PC, Chan AW, Chan HY, Chu ES, Cheng AS, Chim AM, Chan FK, Sung JJ, Chan HL. Interaction of adipokines and hepatitis B virus on histological liver injury in the Chinese. The American journal of gastroenterology. 2010; 105:132-138.

37. Hui CK, Zhang HY, Lee NP, Chan W, Yueng YH, Leung KW, Lu L, Leung N, Lo CM, Fan ST, Luk JM, Xu A, Lam KS, et al. Serum adiponectin is increased in advancing liver fibrosis and declines with reduction in fibrosis in chronic hepatitis B. J Hepatol. 2007; 47:191-202.
38. Ramcharran D, Wahed AS, Conjeevaram HS, Evans RW, Wang T, Belle SH, Yee LJ. Associations between serum lipids and hepatitis $\mathrm{C}$ antiviral treatment efficacy. Hepatology (Baltimore, Md). 2010; 52:854-863.

39. Johnson NA, Walton DW, Sachinwalla T, Thompson $\mathrm{CH}$, Smith K, Ruell PA, Stannard SR, George J. Noninvasive assessment of hepatic lipid composition: Advancing understanding and management of fatty liver disorders. Hepatology (Baltimore, Md). 2008; 47:1513-1523.

40. Zelber-Sagi S, Nitzan-Kaluski D, Goldsmith R, Webb M, Blendis L, Halpern Z, Oren R. Long term nutritional intake and the risk for non-alcoholic fatty liver disease (NAFLD): a population based study. J Hepatol. 2007; 47:711-717.

41. Keating SE, Hackett DA, George J, Johnson NA. Exercise and non-alcoholic fatty liver disease: a systematic review and meta-analysis. J Hepatol. 2012; 57:157-166.

42. Sullivan S, Kirk EP, Patterson B, Klein S. Effect of Endurance Exercise on Non-Alcoholic Fatty Liver Disease. Gastroenterology. 2011; 140:S-700.

43. Hallsworth K, Fattakhova G, Hollingsworth KG, Thoma C, Moore S, Taylor R, Day CP, Trenell MI. Resistance exercise reduces liver fat and its mediators in non-alcoholic fatty liver disease independent of weight loss. Gut. 2011; 60:1278-1283.

44. Stang A. Critical evaluation of the Newcastle-Ottawa scale for the assessment of the quality of nonrandomized studies in meta-analyses. European Journal of Epidemiology. 2010; 25:603-605.

45. Zhu W, Meng YF, Wu Y, Xu M, Lu J. Association of alcohol intake with risk of diabetic retinopathy: a meta-analysis of observational studies. Sci Rep. 2017; 7:4.

46. Zhang YP, Li WQ, Sun YL, Zhu RT, Wang WJ. Systematic review with meta-analysis: coffee consumption and the risk of gallstone disease. Alimentary pharmacology \& therapeutics. 2015; 42:637-648.

47. DerSimonian R, Laird N. Meta-analysis in clinical trials. Control Clin Trials. 1986; 7:177-188.

48. Higgins JPT, Thompson SG. Quantifying heterogeneity in a meta-analysis. Statistics in Medicine. 2002; 21:1539-1558.

49. Sterne JA, Sutton AJ, Ioannidis JP, Terrin N, Jones DR, Lau J, Carpenter J, Rucker G, Harbord RM, Schmid CH, Tetzlaff J, Deeks JJ, Peters J, et al. Recommendations for examining and interpreting funnel plot asymmetry in metaanalyses of randomised controlled trials. BMJ (Clinical research ed). 2011; 343:d4002. 